\title{
Üniversite Öğrencilerinin Mutluluk Korkusu ve Duygularını İfade Etme Becerileri Arasındaki İlişkide Öz Duyarlılığın Aracı Rolü
}

\section{The Mediating Rrole of Self-Compassion in the Relationship Between University Students' Fear of Happiness and Expressing Their Emotions}

\author{
Halil EKŞi ${ }^{1}$, Kadriye iKiZ² ${ }^{2}$ Münevver BAŞMAN ${ }^{3}$
}

\section{Öz}

Bu araştırmanın amacı, üniversite öğrencilerinin mutluluk korkusu ve duygularını ifade etme becerileri arasındaki ilişkide öz duyarlılığın aracı rolünü incelemektir. Bu çalışmanın örneklemi Marmara Üniversitesi'nde 2017-2018 eğitimöğretim yılında çeşitli lisans programlarına devam eden ve tabakalı örnekleme yöntemi ile belirlenen 296 öğrenciden oluşmaktadır. Veri toplama araçları olarak, Kişisel Bilgi Formu, Mutluluk Korkusu Ölçeği, Özduyarlılık Ölçeği ve Duyguları İfade Etme Ölçeği kullanıımıştır. Araştırma yapısal eşitlik modeline göre gerçekleştirilmiştir. Ayrıca değişkenler arasındaki ilişkiyi incelemek için Pearson Momentler çarpım korelasyonu, cinsiyet açısından farklılaşma için Bağımsız gruplar t testi analizi yapılmıştır. Araştırma sonuçlarına göre, mutluluk korkusu ile öz duyarlılık arasında negatif yönlü bir ilişki bulunurken; öz duyarlılık ile duygularını ifade etme arasında pozitif yönlü bir ilişki bulunmaktadır. Mutluluk korkusu azaldıkça öz duyarlıık artmakta ve öz duyarlıık arttıkça da duygularını ifade etme kolaylaşmaktadır. Elde edilen sonuçlara göre öz duyarlıık, mutluluk korkusu ve duygularını ifade etme ilişkisinde aracı bir değişkendir. Ayrıca araştırma değişkenlerinin cinsiyete göre karşılaştırmasında, yalnızca duygularını ifade etme değişkeninin kız öğrenciler lehine manidar bir farklılık gösterdiği bulunmuştur.

Anahtar Kelimeler: Duyguları ifade etme becerisi, mutluluk korkusu, özduyarlılık

\section{Abstract}

The purpose of this research is to examine the mediating role of self-compassion in relation to the fear of happiness and the ability of university students to express their feelings. The sample consisted of 296 students who were selected by stratified sampling method among the students attending various undergraduate programs at Marmara University in the academic year of 2017-2018. "Personal Information Form", "Fear of Happiness Scale", "SelfCompassion Scale" and "Emotional Expression Scale" were used as data collection tools. The research was carried out according to the model of structural equality. In addition, Pearson Product-Moment Correlation Coefficient test was used to examine the relationship between variables, and Independent Samples $t$ Test analysis was performed for gender difference. According to the results of the research, there is a negative relationship between fear of happiness and self-compassion; there is a positive relationship between self-compassion and expressing emotions. As fear of happiness decreases, self-compassion increases and it becomes easier to express feelings as self-compassion increases. According to the results obtained, self-compassion is an mediator variable in relation to expressing fear of happiness and express their feelings. Furthermore, in comparison of the research variables by sex, only the variables expressing emotions were found to be significantly different in favor of female students.

Keywords: Emotional expression, fear of happiness, self-compassion

\footnotetext{
${ }^{1}$ Marmara Üniversitesi, Atatürk Eğitim Fakültesi, Eğitim Bilimleri Bölümü, İstanbul Türkiye, https://orcid.org/0000-0001-7520-4559

${ }^{2}$ Marmara Üniversitesi, Eğitim Bilimleri Enstitüsü, Yüksek Lisans Öğrencisi, İstanbul Türkiye, https://orcid.org/0000-0002-7377-6606

${ }^{3}$ Marmara Üniversitesi, Atatürk Eğitim Fakültesi, Eğitim Bilimleri Bölümü, İstanbul türkiye, https://orcid.org/0000-0003-3572-7982

Atıf / Citation: Ekşi, H., \& İkiz, K., \& Başman, M. (2020). Üniversite öğrencilerinin mutluluk korkusu ve duygularını ifade etme becerileri arasındaki ilişkide öz duyarlılı̆ın aracı rolü. Kastamonu Education Journal, 28(2), 820-829. doi:10.24106/kefdergi.702904
} 


\section{Extended Abstract}

Purpose: The aim of this study is to examine the mediating role of self-compassion in the relationship between university students' fear of happiness and their ability to express emotions. For this purpose it has been sought answers to the following questions:

1. Is there a significant relationship between the fear of happiness, self-compassion, and expression of emotions?

2. Does the fear of happiness, self-compassion and scores of expressing emotions differ significantly according to gender?

3. Is the theoretical model established to verify the mediating role of self-compassion in the relationship between fear of happiness and the ability to express emotion?

Method: The research was carried out according to structural equation modeling. The population of the study group consisted of 5605 students attending Marmara University Atatürk Faculty of Education at the undergraduate level in the spring term of 2017-2018 academic year. A total of 296 students, 219 (74\%) women and 77 (26\%) men, were selected from the population by stratified sampling method. "Personal Information Form", "Fear of Happiness Scale", "Self-Compassion Scale" and "Emotional Expression Scale" were used in the study. The data obtained from the study were analyzed by using the SPSS 15.0 package program. In addition, Pearson Product-Moment Correlation Coefficient test was used to examine the relationship between variables, and Independent Samples $t$ Test analysis was performed for gender difference. The theoretical model, which was created in order to reveal the mediating role of self-compassion in the relationship between fear of happiness and the skills of expressing emotions, was tested through path analysis. The Sobel test developed by Sobel was used to determine to what extent the mediation effect of the self-compassion variable.

Findings: Pearson Moments Product Correlation was used to determine whether there was a significant relationship between the fear of happiness, self-compassion and expressing emotions, which is the first aim of the study. There is a significant negative relationship between the fear of happiness, which is the independent variable of the study and the expressing the emotions, which is the dependent variable $(r=-.28 ; p<.01)$. Self-compassion, which is the mediate variable of he study, is in a negative relationship with the fear of happiness $(r=-.52 ; p<.01)$ and a positive relationship with the expression of emotion $(r=.15$; $p<.05)$. Independent Group $t$ Test was used to determine whether scores of the fear of happiness, self-compassion and expressing emotion, which is the second aim of the study, show significant difference according to gender. In the sample group of the students a significant difference was found only between the expression of emotions and gender groups $(t=5,773 ; p<.01)$. The fear of happiness and self-compassion didn't differ significantly in terms of gender groups ( $p>.05)$. According to the results of the mediator model tested by path analysis, there is a negative relationship between the fear of happiness and self-compassion. In addition, self-compassion has a positive effect on expressing emotions. The results show that as the fear of happiness decreases, self-compassion increases and as self-compassion increases, it is easier to express emotions. According to the Sobel test results, self-compassion has a significant effect on predicting the emotion expression of the fear of happiness variable.

Discussion and Conclusion: When we look at gender differentiation, there is a significant difference between female and male students in terms of expressing emotion. However, there is no significant difference in terms of fear of happiness and selfcompassion. In a meta-analysis study conducted by Yarnell et al. (2015), differences of self-compassion on gender were examined; a small but significant difference was found between male and female groups in favor of males. The finding that women have less self-compassion compared to men is explained by the idea that women tend to be more critical for themselves. However, the fact that women have high levels of compassion for others, compassion as a teachable skill and sharing most of the explained variable in in female-male self-compassion have predicted that gender differences in self-compassion should not be over-emphasized (Yarnell et al., 2015). A meaningful difference was obtained in terms of expressing emotions and gender groups in favor of female students. The need for men to stand harder, steeper and stronger, not to express their feelings expect for anger is supported by culture, while women are fed more to express their feelings. Considering the high proportion of women in the study, new studies on expressing emotions and gender variable can be done. Joshanloo (2013) examined the relationship between the fear of happiness and life satisfaction and presented the first evidence that the fear of happiness influenced the responses of people to the items on the life satisfaction scale in the Iranian sample. Joshanloo (2017) examined the mediating role of optimism in the effect of happiness fragility and fear of happiness the found that the fear of happiness is in a negative relationship with happiness and when the optimism dimension was effective, the relationship was a more moderate. Joshanloo emphasized the need for identifying potential moderators of happiness for subsequent studies. There is no Turkish study on the variables that can mediate fear of happiness. As a result of the analyzes, the mediating role of the self-compassion in the relationship between the fear of happiness and the expression of the emotions was tested. aln addition, research data have been obtained from students studying at Atatürk Faculty of Education of Marmara University and they are limited in terms of generalizability. In larger sample groups, the study can be repeated. In spite of the limitations, it is thought that the research will make an important contribution to the positive psychology literature and will lead the future research to understand the concept of fear of happiness.

As a result, individuals with higher self-compassion will have less extreme reactions, less negative emotions (Yarnell et al., 2015). It can be said that the feeling of happiness, which is avoided and feared, will be experienced more by means of selfcompassion and thus it will be easier to express emotions. 


\section{Giriş}

Mutluluğun kırılgan ve uçucu olduğu inancı bireyler ve kültürler arasında yaygındır (Joshanloo ve diğerleri, 2015). Batı kültürü mutluluğu, bireylerin istediği bir olgu ve birey hayatına yön veren en önemli değerlerden biri kabul eder (Joshanloo ve Weijers, 2014). Mutluluk yıllardır felsefe ve psikolojinin konusu olmuştur. Örneğin, Platon "en yüksek iyi, mutluluktur" demiş; Farabi, insan eylemlerinin gayesine mutluluğu yerleştirmiştir (Akarsu, 1998; Hammond, 2001). Günümüze doğru çağdaşlaşma ile birlikte bireylerin mutluluk üzerindeki kontrolünün önemi dünya çapında artmış görünmektedir (Joshanloo ve diğerleri, 2015). Mutluluk, yaşam doyumu ve olumsuz duygular üzerinde pozitifliğin üstünlüğü ile ayırt edilir (Joshanloo ve Weijers, 2014). Alanyazında öznel iyi oluş olarak tanımlanan mutluluk; bireyin yaşadığı olumlu-olumsuz duygularla birlikte kendi yaşam doyumuna dair yaptığı öznel ve bireyin kendi yaşam kalitesinin genel bilişsel değerlendirmesidir (Diener, 1984; Akt., Malkoç, 2011; Uchida, Norasakkunkit ve Kitayama, 2004).

Kültür, insan zihnini anlamanın, paylaşılan inanç değer ve uygulamaların merkezindedir ve mutluluk düzeylerindeki farklııılar değer sistemindeki kültürel farklılıklarla ilgilidir (Muhtar, 2016). Birtakım araştırmacılar bireysel kültürlerde kişisel mutluluğun kolektivist kültürlerden daha güçlü bir şekilde vurgulandığını ifade eder (Joshanloo ve Weijers, 2014). Sanayileşmiş, bireyci batılı ülkelerdeki benlikten duyulan memnuniyet, yaşam doyumuyla güçlü bir şekilde ilişkilendirilirken (Diener, Oishi ve Lucaas, 2003) kolektivist kültürlerde, bireyin amacı, kendisini veya başkalarını diğerlerinden ayırmak değil, onlarla uyum sağlamaktır (Diener, Suh, Lucas ve Smith, 1999). Özellikle, Kuzey Amerika kültürel bağlamlarında mutluluk, kişisel başarı açısından tanımlanma eğilimindedir. Bu eğilim çoğu zaman, bireyin bireysel çabalar yoluyla sürdürdüğü ve elde ettiği içsel niteliklerden biri olarak yorumlanır. Asya kültürel bağlamlarında ise mutluluk, kişilerarası bağlar açısından tanımlanma eğilimindedir (Uchida, Norasakkunkit ve Kitayama, 2004). Batılılar, Aydınlanma ile birlikte gelen insani kontrol, özerklik ve rasyonaliteye yapılan vurgu ile mutluluk dahil yaşam ilişkilerini daha fazla kontrol etmeye başlamış; mutluluğun doğal ve devredilemez bir hak olduğu, bireyin mutluluğunun peşinden koşmada sorumlu olduğu inancını geliştirmiştir (Gilmour, 2006; Joshanloo ve diğerleri, 2015; Akt., Joshanloo ve Weijers, 2014).

Diğer taraftan Doğu kültürlerinde mutluluk, Batı kültürüne göre daha az değer görmektedir (Joshanloo ve Weijers, 2014). Bazı Asya kültürlerinde bireyin mutluluğunun bir sınırı olması gerektiği öngörülür (Joshanloo, 2013). Özellikle Çin halkının yüksek düzeyde mutluluktan kaçındığı, her şeyin tersine dönme eğiliminde olduğu; kişisel zevke dayalı mutluluk çabalarının utanç verici oluşu, mutluluk ve mutsuzluğun diyalektik dengesini güçlü şekilde desteklediği görülmektedir (Lu, 2001; Muhtar, 2016; Akt., Joshanloo ve Weijers, 2014). İran'da ise hüzün, derinlikle ilişkiliyken mutlu bir birey sığ ve gürültülü olarak tanımlanır (Joshanloo, 2013). Japon kültüründe mutluluk negatif kabul edilmekte, acı çekmeye neden olabileceğinden tehlikeli olarak görülmektedir (Minami, 1971; Akt., Joshanloo, 2013). Özetle birçok kültürün mutluluğa dair olumsuz görüşlere sahip olduğu, özellikle aşırı mutluluğun mutsuzluğa yol açtığı ve bazen mutluluktan kaçındığı görülmektedir. Olumlu duygular korkusu, onları deneyimleme yetisine sahipken bu duygulardan kaçınmayı içerir (Gilbert, McEwan, Catarino, Baiao ve Palmeira, 2014). Mutluluk korkusu, mutluluğun olumsuz sonuçlara neden olacağı düşüncesi ile ondan kaçınılması gerektiği inancı olarak tanımlanmıştır (Joshanloo, 2014). Mutluluğa karşı çıkmayı destekleyen inançlar Joshanloo ve Weijers (2014) tarafından şu şekilde özetlenir; mutlu olmak kötü şeylerin olmasını daha muhtemel kılar, sizi kötü bir birey yapar, mutluluğun peşinde koşmak kötüdür, çünkü ölüm ve ıstırap mutlu bireylerin peşindedir. Uchida, Norasakkunkit ve Kitayama'ya (2004) göre kişisel mutluluk, toplumsal ilişkiyi yitirir; benliğin başarısının vurgulanması, başkaları tarafından kıskançlığa yol açabilir. Mutluluğa katkıda bulunan birçok dış etken kontrolümüz dışındadır ve yapılan hiçbir eylem mutluluğu garanti edemez (Joshanloo ve diğerleri, 2015). Böylece mutluluğun hiçbir hali sonsuz değildir. Gilbert ve diğerleri (2014), olumlu duyguların her zaman haz vermediği gibi mutluluk korkusuna neden olabileceğini ifade etmiş ve bazı olası nedenlerini belirtmiştir: Çocukların olumlu bir duygunun tadını çıkarırken tehdit edilmesi veya cezalandıııması, mutsuz bir ailede bulunması, hasta bir ebeveyninin yanında eğlendiği için kendini suçlu hisseden çocukların uyumsuz şemalar geliştirmesi mutluluk korkusuna neden olabilir. Muhtar'a (2016) göre Joshanloo'nun mutluluk korkusunu terimleştirmesi, iyi olma ve kültüre özgü inançların anlaşılması için yeni bir kapı açmıştır. Gilbert ve diğerleri (2012) şefkat ve mutluluk korkusu arasındaki ilişkiyi araştırmış, bunlara duyulan korkunun; aleksitimi, dikkat, empati, öz eleştiri, depresyon, kaygı ve stres ile bağlantılı olduğunu bulmuştur. Olumlu duygular korkularını ele almak adına gerçekleştirilecek müdahalenin önemli hedeflerinden biri, duygusal düzenlemede yardımcı kendine sıcaklık ve öz-duyarlılı̆ı geliştirmek; olumsuz duygularla başa çıkmada kendine ve başkalarına merhamet sahibi olmaktır (Gilbert ve diğerleri, 2014).

Kendine merhamete duyulan ilgi, nispeten yeni bir alandır (Yarnell ve diğerleri, 2015). Öz duyarlık batılı psikologlar için yeni bir kavram olmasına rağmen doğulu filozoflar tarafından yüzyıllardır bilinmektedir (Akın, Akın ve Abacı, 2007). Merhamet, başkalarının acılarına açık olmayı ve onları hareket ettirmeyi içerir; böylece birey, acılarını hafifletmeyi arzu 
eder (Neff, 2003). Aynı şekilde öz-duyarılık, bireyin kendi acılarına açık olma ve onu hareket ettirmesini, şefkat duyguları yaşayarak bireyin kendi yetersizliklerine ve başarısızlıklarına karşı bir anlayış, gerçekçi bir tavır takınmasını içerir. Neff (2009), öz duyarlılığı üç bileşene ayırmış ve şu şekilde tanımlamıştır: Öz sevecenliğe karşı öz yargılama, bilinçli farkındalığa karşı aşııı özdeşleşme ve paylaşımların bilincinde olmaya karşı izolasyon. Öz duyarlılı̆ın bileşenleri farklı şekilde deneyimlenir ve kavramsal olarak farklıdır, ama aynı zamanda birbirini etkileme eğilimindedir (Neff, 2003). Bireyler özeleştirel olduğunda kendi duygularını keşfetme kabiliyeti zorlaşır, çünkü birey kendini güvende hissetmez (Gilbert ve diğerleri, 2014). Öz duyarlılık gelişimine evrimsel psikolojiden bakan Gilbert (2009), kendini eleştirme tehtidine karşı öz duyarlılığın güvenlik sistemini devreye koyduğunu söylemiştir (Yarnell ve diğerleri, 2015). Öfke, bireyler hakarete uğradığında ya da aşağılanmış hissettiklerinde ve kendi bakış açılarına bağlı olmanın bireye katı bir haklılık sunduğu zamanlarda ortaya çıkar (Neff ve Vonk, 2009). Bireyler sınırlamalarla karşılaştığında ortaya çıkan kendilik, olumsuz düşüncelere ve bir tür yalnızlığa sebep olabilir. Bireyler bu yaşantının insanlığın ortak deneyimi olduğunu unuttuğunda olumsuz duygular şiddetlenir ve izolasyon ortaya çıkabilir. Aynı şekilde, üzüntü ve kişisel başarısızlıkların başkaları ile paylaşıldığının farkına varmak, suçluluk derecesini ve kendini acımasızca eleştirmeyi azaltır, duyguların eşsizliğini ve izolasyonunu yumuşatabilir. (Neff, 2003). Özetle öz duyarlıık, olumsuzlukları ve zayıflıkları göz önünde bulundurarak birey olmanın kusurlu olduğunu, birbirinin hatalarından öğrenmeyi, aynı zamanda olumsuz duygu ve düşüncelere dikkatli ve nötr olarak yaklaşmayı içerir (Yarnell ve diğerleri, 2015).

Neff ve Vonk (2009)'un yaptıkları araştırmaya göre öz duyarlılık benlik saygısından daha fazla özgüven duygusunu yordamaktadır. Öz duyarlılık sosyal karşılaştırma, öfke ve bilişsel kapamayla negatif ilişkideyken benlik saygısı narsizm ile pozitif ilişkili bulunmuştur. Öz duyarlılık ben merkezli olmayı gerektirmez, doğrudan şefkat duygusuyla bağdaşır ve yetersizliklerin birey koşullarının bir parçası olduğunu kabul etmeyi gerektirir (Neff, 2003). Benlik saygısı, daha büyük mutluluk ve yaşam doyumunun yanı sıra narsizm ile de yüksek ilişki göstererek (Neff, 2009) başkalarıyla olan farklılığı vurgularken öz duyarlıık aradaki benzerlikle ilgilenir (Neff ve Vonk, 2009). Neff'in (2003) kavramsallaştırmasında öz duyarlılık, kendilik değerinin değişmezliğini içeren sağlıkı bir duruşa sahip olmanın bir yoludur. Öz duyarılık kendiliğini yükseltmek ya da başkalarını aşağı çekmek istemeyen bir anlam ilişkisi sunar. Anlam ise bireyin kendi dahil tüm varlıklar için şefkat ve ortak paydada olduğumuzun kabulü ile başlar (Neff ve Vonk, 2009). Öz-duyarlıık, acı verici ya da üzücü duygular önlenemediğinde; iyilik, anlayış ve ortak paylaşılan insanlık deneyimi ile farkındalık içinde tutulduğunda duygu düzenlemede faydalı bir strateji olarak görülebilir. Bu sayede olumsuz duygular, olumlu duygu hali alma eğilimindedir ve bireyin kendi durumuna daha nötr odaklanmasına, kendini ve çevresini uygun ve etkili bir şekilde değiştirmesine izin verir (Folkman ve Moskowitz, 2000; Isen, 2000; Akt., Neff, 2003). Bununla birlikte Yarnell ve diğerleri (2015), bugüne kadarki araştırma ve müdahalelerde öz duyarlık açısından potansiyel cinsiyet farklııklarının dikkate alınmadığını bildirir. Yaptıkları meta-analiz çalışmasında, özduyarlıı̆̆ın cinsiyet üzerindeki farklılıkları incelenmiş, kadın-erkek grupları arasında erkekler lehine küçük ama anlamlı bir farklılık bulunmuştur. Elde edilen bulgu, kadınların kendileri için daha eleştirel olma eğiliminde oldukları ve erkeklere göre daha fazla olumsuz kendi kendine konuşma kullandıkları düşüncesiyle açıklanmıştır. Bunun yanı sıra mevcut bazı meta-analizler kadınların daha düşük özgüvene sahip olduğunu gösterir. Ancak kadınların daha empatik ve başkalarına şefkat düzeylerinin yüksek oluşu, şefkatin öğretilebilir bir beceri olması ve kadın-erkek öz duyarlılık düzeylerindeki açıklanan varyansın çoğunun paylaşılması, öz-duyarlılık içindeki cinsiyet farklıııklarının aşırı vurgulanmaması gerektiğini öngörmektedir (Yarnell ve diğerleri, 2015).

Duygu, düşünce kavramından farklı bir beyin olgusudur ve kendine has fizyolojik temeli, beyin içinde konuşan bir dili vardır; bir his ve bu hisse özgü belirli düşüncelerdir (Goleman, 2001; Greenberg, 2015). Sosyobiyologlara göre duygular; tehlike, acı bir kayıp, hedefe doğru ilerleme, aile kurma gibi yalnızca akla bırakılmayacak durumlarda yol göstericidir (Goleman, 2001). Duygu çalışmalarında en az altı duygu tanımlanmış (kızgınlık, korku, üzüntü, iğrenme, şaşırma, neşe) ve bunlara dair yüz ifadelerinin doğuştan olduğu, duyguların evrensel dilinin bireyleri birbirine bağladığı ifade edilmiştir (Greenberg, 2015). Duyguları ifade etmek daha iyi anlamayı sağlamanın yanında bilişsel bir rahatlama da sunmaktadır (Zech, 1998; Akt., Kuyumcu, 2011). Duyguların ifadesi kültür tarafından şekillenen karışık bir duygusal zeka becerisidir (Goleman, 2001; Greenberg, 2015). Örneğin bir kayıp yaşandığında acı ve üzüntüyü ifade ediş tarzı sosyal olarak yönlendirilir. Duyguya dair araştırmalar duygusal yaşantıya ilişkin dört değişken üzerinde odaklanır. Bu ögeler Parkinson ve Colman (1995) tarafından durumsal değerlendirme, bedensel değişimler, harekete geçirilmiş eylemler ve duyguları ifade davranışı olarak tanımlanır. Bu ögelerden duyguları ifade davranışı, duyguların kişilerarası ilişkilerde vurgulanmasıdır (Akt: Adıgüzel, 2012). Mutluluk korkusuna dair Türkiye'de yapılan çalışmalar incelendiğinde yapılan tek ilişkisel çalışma Sarı ve Çakır (2016) tarafından gerçekleştirilen mutluluk korkusu ile öznel ve psikolojik iyi oluş arasındaki ilişkinin incelenmesidir. Mutluluk korkusu ile öznel iyi oluş ve psikolojik iyi oluş arasında düşük düzeyde negatif bir ilişki olduğu ve mutluluk korkusunun hem öznel iyi oluşu hem de psikolojik iyi oluşu anlamlı olarak negatif yönde yordadığı bulunmuştur. Illgili alanyazından hareketle mutluluk korkusunun özellikle olumlu duyguları ifade 
etmede negatif ilişki göstereceği, öz duyarlığın ise mutluluk korkusunu azaltarak aracılık edeceği düşünülmektedir. Bu araştırmanın amacı üniversite öğrencilerinin mutluluk korkusu ve duygularını ifade etme becerileri arasındaki ilişkide öz duyarlılığın aracı rolünü incelemektir. Aynı zamanda kültürün duygu ifadesi konusunda bireyleri eğitmesi, Yarnell ve diğerleri (2015)’nin yaptıkları çalışmada öz duyarlık açısından cinsiyet gruplarında küçük de olsa anlamlı bir farklılığın bulunması bu çalışmanın cinsiyet değişkeni açısından da ele alınmasını sağlamıştır. Henüz bu yönde yapılmış bir araştırmaya rastlanmamıştır, dolayısıyla bu araştırma bulgularının özellikle mutluluk alanyazınına ve yeni araştırmalara katkı sağlayacağı düşünülmektedir. Bu bağlamda üniversite öğrencilerinin mutluluk korkusu ve duygularını ifade etme becerileri arasındaki ilişkide öz-duyarlılığın aracı rolünün incelenmesi gerekli bulunmaktadır. Bu amaç doğrultusunda aşağıdaki sorulara yanıt aranmıştır:

1. Mutluluk korkusu, öz duyarlılık ve duygularını ifade etme değişkenleri arasında manidar bir ilişki bulunmakta midır?

2. Mutluluk korkusu, öz duyarlılık ve duygularını ifade etme puanları cinsiyete göre manidar bir farklılık göstermekte midir?

3. Mutluluk korkusu ile duygularını ifade etme becerileri arasındaki ilişkide özduyarlılığın aracı rolünü ortaya koymak amacıyla oluşturulan kuramsal model doğrulanmakta mıdır?

\section{Yöntem}

\section{Araştırmanın Modeli}

Bu araştırmada yapısal eşitlik modeli kullanılmıştır. Yapısal eşitlik modeli, birden fazla istatistiksel yöntemin ve gizil yapıları gözlenen değişkenler aracılığıyla incelemeye izin veren tekniklerin genel adı; gözlenen ve gizil değişkenler arası ilişkiler hakkındaki hipotezlerin test edilmesine olanak sağlayan kapsamlı istatistiksel yaklaşımdır (Jöreskog ve Sörbom, 1993; Hoyle, 1995; Akt., Çokluk, Şekercioğlu ve Büyüköztürk, 2012).

\section{Evren ve Örneklem}

Araştırmanın evrenini 2017-2018 eğitim-öğretim yılı bahar döneminde Marmara Üniversitesi Atatürk Eğitim Fakültesi'nde lisans düzeyinde öğrenim görmekte olan 5605 öğrenci oluşturmaktadır. Araştırmanın örneklem grubu, evrenden tabakalı örnekleme yöntemi ile seçilen Atatürk Eğitim Fakültesinde öğrenim gören öğrencilerinden oluşmaktadır. Öncelikle tabakalı örnekleme yöntemine bağlı olarak, üniversiteye yerleşmede etkili olan puan türü dikkate alınmış; Sayısal, Sözel, Eşit Ağırlık, Dil ve Özel Yetenek puan türleri ile öğrenci alan bölümler olmak üzere her puan türü tabaka olarak kabul edilmiş, böylece 4 tabaka oluşturulmuştur. Araştırmanın örneklem büyüklüğü, homojen olmayan evren için \% 95 güven aralığında, \pm \% 5 örnekleme hatası ile $n=360$ olarak hesaplanmıştır (Salant ve Dillman, 1994). Tabaka oranları incelendiğinde öğrencilerin \% 23,41'inin (84) sayısal, \% 33,43'ünün (120) sözel, \% 15,61'inin (56) eşit ağılık, \% 27,55'inin (100) dil ve özel yetenek puanı ile üniversiteye yerleştiği görülmektedir. Olası veri kayıpları da dikkate alınarak 380 kişiye ulaşılmış; kayıp veriler, tek ve çok yönlü uç değerler incelenmiş, örneklem sayısı 296 olarak belirlenmiştir. Araştırma örneklemini, evrenden seçilen 17-58 yaş aralığında 219 (\%74) kadın ve 77 (\%26) erkek, toplam 296 öğrenci oluşturmaktadır. Örneklemin \%48,6'sı (144) 1. sınıf, \%7.4'ü (22) 2. sınıf, \% 22,0'ı (65) 3. sınıf ve \% 22,0'ı (65) 4. sınıf öğrencilerinden oluşmaktadır.

\section{Veri Toplama Araçları}

Araştırmada Kişisel Bilgi Formu, Mutluluk Korkusu Ölçeği, Öz Duyarlılık Ölçeği ve Duyguları Ífade Etme Ölçeği veri toplama aracı olarak kullanılmıştır.

Kişisel Bilgi Formu: Araştırmacı tarafından belirlenen, katılımcılara ait; cinsiyet, yaş, sınıf, algılanan toplam gelir düzeyi, anne-baba eğitim durumu ve kardeş sayısı değişkenlerinden oluşmaktadır.

Mutluluk Korkusu Ölçeği: Mutluluk Korkusu Ölçeği, Joshanloo tarafından 2013 yılında geliştirilmiş, kültürümüze uyarlaması Demirci, Ekşi, Kardaş ve Dinçer (2016) tarafından yapılmıştır. 5 maddeden oluşan ölçek, 1'den (kesinlikle katılmıyorum) 7'ye (kesinlikle katılıyorum) doğru giden 7'li likert tipi bir derecelendirmeye dayanır. Ölçekte ters madde bulunmamaktadır. Ölçekten alınan puan yükseldikçe mutluluk korkusu yükselmektedir. Doğrulayıcı faktör analizinde tek boyutlu modelin iyi uyum verdiği görülmüştür. Ölçekteki maddelerin faktör yükleri .71 ile .92 arasında değişmektedir. Ölçeğin madde toplam puan korelasyon katsayılarının .65 ile .83 arasında değiştiği görülmüştür. Ölçeğin iç tutarlılık güvenirlik katsayısı .90 olarak hesaplanmıştır (Demirci, Ekşi, Kardaş ve Dinçer, 2016).

Öz Duyarlıık Ölçeği: Öz Duyarlılık Ölçeği (ÖDÖ), Neff (2003), tarafından geliştirilmiş öz bildirim türü bir ölçektir. 26 maddeden oluşan ölçek 1'den (hiçbir zaman) 5'e (her zaman) doğru giden 5'li likert tarzı bir derecelendirmeye dayanır. Altı alt boyuttan oluşmaktadır. Bunlar Öz Sevecenlik $(2,6,13,17,21)$, Öz Yargılama $(4,7,15,20,26)$, 
Paylaşımların Bilincinde Olma $(1,8,12,22)$, İzolasyon $(5,11,19,25)$, Bilinçlilik $(9,14,18,23)$ ve Aşırı Özdeşleşme'dir $(3,10,16,24)$. Bireyin her bir alt ölçekten elde ettiği puanların yüksek olması bireyin ilgili alt ölçeğin değerlendirdiği özelliklere sahip olduğunu göstermektedir. Ölçeğin Türkçeye uyarlama, güvenirlik ve geçerlilik çalışmaları Akın, Akın ve Abacı (2007) tarafından yapılmıştır. Yapılan doğrulayıcı faktör analizinde ölçeğin orijinal formla uyumlu olduğu görülmüştür. Ölçeğin iç tutarlılık katsayıların .72 ile .80 , test-tekrar test güvenirlik katsayıları ise .56 ile .69 arasında bulunmuştur. Ayrıca ölçeğin düzeltilmiş madde-toplam korelasyonlarının .48 ile .71 arasında sıralandığı ve \%27'lik altüst grupların ortalamaları arasındaki tüm farkların anlamlı olduğu bulunmuştur (Akın, Akın ve Abacı, 2007).

Duyguları Ifade Etme Ölçeği: Duyguları Ifade Ölçeği, King ve Emmons tarafından, bireylerin duygularını ifade etme eğilimlerini ölçmek için geliştirilmiş; kültürümüze uyarlaması, Kuzucu (2006) tarafından yapılmıştır. 15 maddeden oluşan 7'li likert tipi derecelendirmeye dayalı ölçeğin maddeleri; olumlu, olumsuz ve yakınlık içeren duyguları ifade etme eğilimini ölçmektedir. Ölçek maddeleri hem olumlu hem de olumsuz duyguları içerecek şekilde oluşturulmuştur. Maddeler, 1 ile 7 arasında puanlanmaktadır. 1, kişinin maddeye kesinlikle katılmadığını, 7 ise kesinlikle katıldığını göstermektedir. Ölçekten alınan yüksek puanlar duyguları ifade etme eğiliminin yüksek olduğunu göstermektedir. Ölçekte tersten puanlanan maddeler 6. ve 14. maddelerdir. Faktör analizi ölçeğin üç boyutlu olduğunu, ancak kimi maddelerin özgün ölçekten farklı faktörlere yüklendiğini göstermektedir. Üç faktör, toplam varyansın \%35'ini açılmaktadır. Test-tekrar test $(n=96, r=.85)$ ve iç tutarlık analizleri $(\alpha=.85)$ ölçeğin güvenilir olduğunu göstermektedir (Kuzucu, 2006).

\section{Bulgular}

Araştırmanın alt amaçları doğrultusunda elde ettiğimiz bulgular aşağıda sunulmaktadır. Araştırmanın ilk alt amacı olan mutluluk korkusu, öz duyarlılık ve duygularını ifade etme değişkenleri arasında manidar bir ilişkinin olup olmadığı Tablo 1'de verilmektedir.

Tablo 1. Araştırma Değişkenlerine ilişkin Ortalama, Standart Sapma ve Korelasyon Değerleri

\begin{tabular}{|c|c|c|c|c|c|}
\hline & Ortalama & Standart Sapma & 1. & 2. & 3. \\
\hline 1. Mutluluk korkusu & 14.03 & 7.62 & 1 & & \\
\hline 2. Öz Duyarlılık & 72.39 & 10.21 & $-.52 * *$ & 1 & \\
\hline 3. Duygularını ifade Etme & 82.50 & 16.91 & $-.28 * *$ & $.15^{*}$ & 1 \\
\hline
\end{tabular}

$*_{\mathrm{p}}<.05 \quad * * \mathrm{p}<.01$

Tablo 1'degörüldüğü üzere araştırmanın bağımsız değişkeni olan mutluluk korkusu ile bağımlı değişken olan duygularını ifade etme arasında ( $r=-.28 ; p<.01)$ negatif yönlü manidar bir ilişki bulunmaktadır. Araştırmanın aracı değişkeni olan öz duyarlılık, mutluluk korkusu değişkeni ile $(r=-.52 ; p<.01)$ negatif yönlü, duygularını ifade etme değişkeni ile $(r=.15 ; p<.05)$ pozitif yönlü manidar bir ilişki içindedir.

Araştırmanın ikinci alt amacı olan mutluluk korkusu, öz duyarlıık ve duygularını ifade etme puanlarının cinsiyete göre manidar bir farklılık gösterip göstermediği Tablo 2'de verilmektedir.

Tablo 2. Mutluluk Korkusu, Öz duyarlılık ve Duygularını İfade Etme Ölçeği Puanlarının Cinsiyete Göre Farklılaşıp Farklılaşmadığını Belirlemek Üzere Yapılan Bağımsız Gruplar t Testi Sonuçları

\begin{tabular}{|c|c|c|c|c|c|c|c|c|}
\hline \multirow{2}{*}{ Puan } & \multirow{2}{*}{ Gruplar } & \multirow{2}{*}{$N$} & \multirow{2}{*}{$\overline{\mathrm{X}}$} & \multirow{2}{*}{$S S$} & \multirow{2}{*}{$\mathrm{Sh}_{\overline{\mathrm{x}}}$} & \multicolumn{3}{|c|}{ t-Testi } \\
\hline & & & & & & $t$ & Sd & $p$ \\
\hline \multirow{2}{*}{ Mutluluk Korkusu } & Erkek & 77 & 14.05 & 7.20 & .821 & \multirow{2}{*}{-.029} & \multirow{2}{*}{294} & \multirow{2}{*}{.977} \\
\hline & Kadın & 219 & 14.02 & 7.78 & .526 & & & \\
\hline \multirow{2}{*}{ Öz duyarlılık } & Erkek & 77 & 81.27 & 15.77 & .763 & \multirow{2}{*}{.785} & \multirow{2}{*}{294} & \multirow{2}{*}{.434} \\
\hline & Kadın & 219 & 82.94 & 17.40 & .176 & & & \\
\hline \multirow{2}{*}{ Duygularını Ifade Etme } & Erkek & 77 & 66.91 & 9.72 & .108 & \multirow{2}{*}{5.773} & \multirow{2}{*}{294} & \multirow{2}{*}{.000} \\
\hline & Kadın & 219 & 74.32 & 9.68 & .654 & & & \\
\hline
\end{tabular}

Tablo 2'de görüldüğü üzere öğrencilerin duygularını ifade etme ölçeği puan ortlamalarında cinsiyete göre manidar bir farklılık bulunmaktayken ( $t=5773 ; p<.01$ ), mutluluk korkusu ve öz duyarlık puan ortalamalarında cinsiyete göre manidar bir farklııı bulunmamaktadır ( $p>05)$. Öğrencilerin duygularını ifade etme ölçeği puan ortalamalarında 
kadınların ( $\bar{x}=74.32)$ erkeklerden (66.91) daha yüksek ortalamaya sahip olduğu görülmektedir. Bu durum kadınların duygularını ifade etme becerilerinin erkeklerden daha yüksek olduğu şeklinde yorumlanabilir.

Mutluluk korkusu ile duygularını ifade etme becerileri arasındaki ilişkide özduyarlılığın aracı rolünü ortaya koymak amacıyla oluşturulan kuramsal model yol analizi yoluyla sınanmıştır. Analiz sonuçları Şekil 1 ve Tablo 3’te verilmiştir.

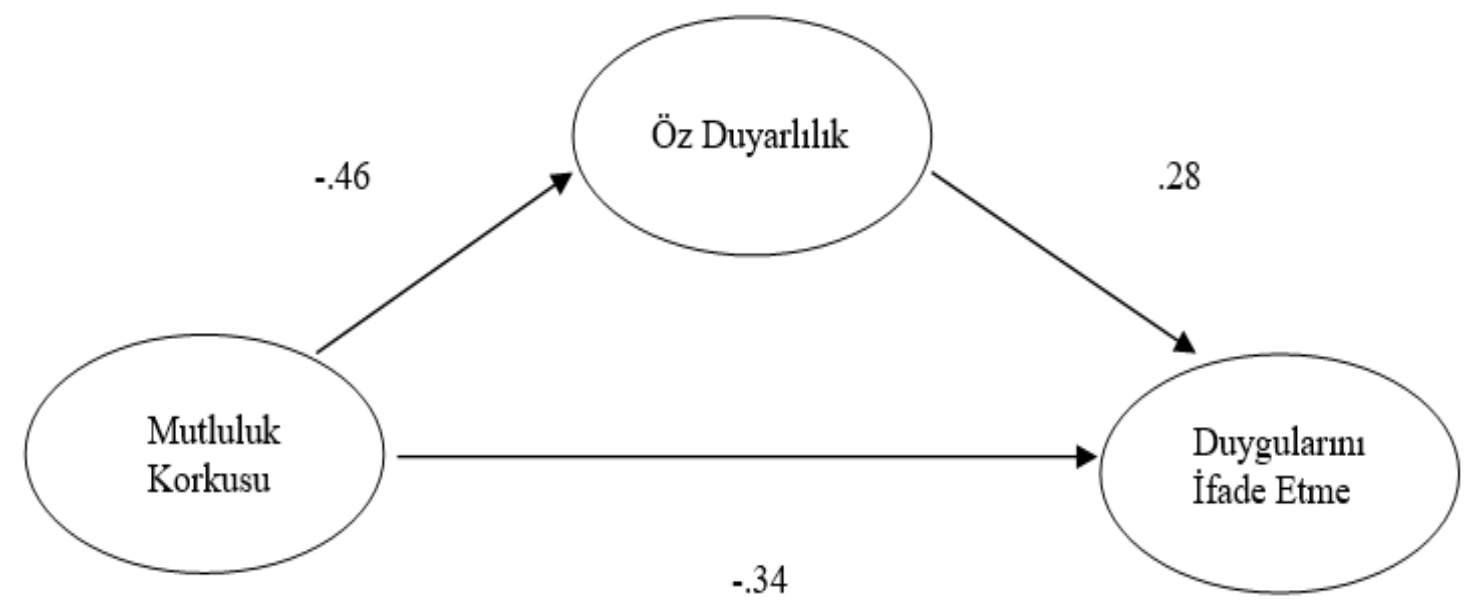

Şekil 1. Kuramsal Model

Aracı model sonuçlarında görüldüğü üzere mutluluk korkusu ile öz-duyarlılık arasında negatif yönlü bir ilişki bulunmaktadır ( $r=-.46$ ). Ayrıca öz duyarlılık duygularını ifade etme üzerinde pozitif yönlü bir etki yapmaktadır ( $r=.28)$. Sonuçlar göstermektedir ki mutluluk korkusu azaldıkça öz-duyarlılık artmakta ve öz-duyarlılık arttıkça da duygularını ifade etme kolaylaşmaktadır ( $r=-.34)$.

Tablo 3. Uyum Analizleri Sonuçları

\begin{tabular}{cccc}
\hline Uyum Indeksleri & Kuramsal Model & $\begin{array}{c}\text { Mükemmel Uyum } \\
\text { Göstergesi Ölçütleri }\end{array}$ & íyi Uyum Göstergesi Ölçütleri \\
\hline$X^{2}$ & 3244.06 & & \\
Sd & 975 & & \\
$X^{2} / s d$ & 3.32 & $\leq 3$ & $3<\mathrm{X}^{2} / \mathrm{sd} \leq 5$ \\
$\mathrm{RMSEA}$ & .08 & $\leq .05$ & $.05<\mathrm{RMSEA} \leq .08$ \\
$\mathrm{AGFI}$ & .94 & $\geq .95$ & $.90 \leq \mathrm{AGFI}<.95$ \\
$\mathrm{GFI}$ & .94 & $\geq .95$ & $.90 \leq \mathrm{GFI}<.95$ \\
$\mathrm{CFI}$ & .91 & $\geq .95$ & $.90 \leq \mathrm{CFI}<.95$ \\
$\mathrm{RMR}$ & .04 & $\leq .05$ & $.05<\mathrm{RMR} \leq .08$ \\
$\mathrm{SRMR}$ & .03 & $\leq .05$ & $.05<\mathrm{SRMR} \leq .08$ \\
$\mathrm{NFI}$ & .92 & $\geq .95$ & $.90 \leq \mathrm{NFI}<.95$ \\
\hline
\end{tabular}

Tablo 3'teki uyum iyiliği istatistikleri incelendiğinde, elde edilen değerlerin mükemmel uyum ve iyi uyum gösterdiği görülmektedir. Modele ilişkin, CFI, RMSEA, AGFI, GFI ve NFI değerleri iyi uyum değerleri arasındayken, $\chi 2 / s d$, RMR ve SRMR mükemmel uyum değerleri vermektedir (Çokluk, Şekercioğlu, Büyüköztürk, 2012).

Modelde yer alan Öz-duyarlıık değişkeninin aracılık etkisinin manidarlık derecesinin bulunması için Sobel tarafından geliştirilen ve kendi ismiyle anılan Sobel Testi kullanılmıştır (Preacher ve Leonardelli, 2012). Sobel Testi analizi sonucunda mutluluk korkusu değişkeninin duygularını ifade etmeyi yordamasında öz duyarlılığın manidar bir etkisinin olduğu görülmektedir ( $z=-2.125, p=.033<.05)$. 


\section{Tartışma ve Sonuç}

Bu çalışmada, üniversite öğrencilerinin mutluluk korkusu ve duygularını ifade etme becerileri arasındaki ilişkide, öz duyarlıı̆̆ın aracı rolünü incelemek amaçlanmıştır. Çalışma bulguları, öz duyarlılı̆ın mutluluk korkusu üzerinde etkili olduğunu ve böylece duyguları ifade etmenin kolaylaştı̆̆ını göstermektedir. Bu bölümde öncelikle cinsiyet, ardından aracı modele ilişkin tartışmaya yer verilmiştir.

Araştırma değişkenlerinin cinsiyete göre farklılık gösterip göstermediğini belirlemek amacıyla yapılan analiz sonucunda duyguları ifade etme değişkeni açısından kadın ve erkek öğrenciler arasında manidar bir farklılık bulunurken; mutluluk korkusu ve öz-duyarlııı değişkenleri açısından manidar bir farklılık bulunmamıştır. Yarnell ve diğerlerinin (2015) yaptığı meta-analiz çalışmasında, öz-duyarlılığın cinsiyet üzerindeki farklılıkları incelenmiş; kadınerkek grupları arasında erkekler lehine küçük ama anlamlı bir farklıık bulunmuştur. Kadınların erkeklere oranla daha az öz-duyarlılığa sahip olduğu bulgusu, kadınların kendileri için daha eleştirel olma eğiliminde oldukları düşüncesiyle açıklanmıştır. Ancak kadınların başkaları için şefkat düzeylerinin yüksek oluşu, şefkatin öğretilebilir bir beceri olması ve kadın-erkek öz duyarlıık düzeylerindeki açıklanan varyansın çoğunun paylaşılması, öz-duyarlılık içindeki cinsiyet farklılıklarının aşırı vurgulanmaması gerektiğini öngörmektedir (Yarnell ve diğerleri, 2015). Ayrıca Özyeşil (2011), üniversite öğrencilerinin öz duyarlık puan ortalamaları arasında manidar düzeyde farklılık bulmamıştır. Bu bakımdan araştırmada elde edilen bulgu, alanyazınla tutarlıdır.

Duyguları ifade etme değişkeni ile cinsiyet grupları arasında kadın öğrenciler lehine manidar bir farklılık elde edilmiştir. Kültür, duygularımızı nasıl yaşamamız gerektiği; saklamamız ya da dışavurmamız konusunda bireyleri eğitmektedir (Goleman, 2001; Greenberg, 2015 ). Kadınların erkeklerden daha çok duygularını ifade ettiği bulgusu, toplumsal cinsiyet rolleri üzerinden tanımlanan erkeklik ve kadınlık rolleri bağlamında açıklanabilir. "Erkek adam ağlamaz." gibi söylemlerde de görüldüğü gibi erkeklerin daha sert, dik ve güçlü durması, öfke dışı duygularını ifade etmemesi gerekliliği kültür tarafından desteklenmektedir. Aynı şekilde kadınların daha çok duygularını ifade etmeleri için beslendiği ifade edilebilir. Araştırmadaki kadın oranının fazlalığı da göz önünde bulundurularak, duyguları ifade etme ve cinsiyet değişkeni üzerine yeni çalışmalar yapılabilir.

Çalışmanın temel amacı kapsamında, mutluluk korkusu ve duygularını ifade etme arasındaki ilişkide özduyarlıı̆̆ın aracı rolü incelenmiş ve manidar aracılık etkilerinin olduğu bulunmuştur. Öz duyarlılık, mutluluğun olumsuz sonuçlara neden olacağı düşüncesi ile ondan kaçınılması gerektiği inancı olarak tanımlanan mutluluk korkusunu azaltmaktadır. Joshanloo (2013) mutluluk korkusu ve yaşam doyumu arasındaki ilişkiyi incelemiş, mutluluk korkusunun İran örnekleminde, bireylerin yaşam doyumu ölçeğindeki maddelere olan yanıtlarını etkilediğini gösteren ilk kanıtları sunmuştur. Mutluluk korkusuna dair Türkiye'de yapılan çalışmalar incelendiğinde ise yapılan tek ilişkisel çalışma Sarı ve Çakır (2016) tarafından gerçekleştirilen mutluluk korkusu ile öznel ve psikolojik iyi oluş arasındaki ilişkinin incelenmesidir. Mutluluk korkusu ile öznel iyi oluş ve psikolojik iyi oluş arasında düşük düzeyde negatif bir ilişki olduğu ve mutluluk korkusunun hem öznel iyi oluşu hem de psikolojik iyi oluşu anlamlı olarak negatif yönde yordadığı bulunmuştur. Bununla birlikte, mutluluğa karşı olumsuz duyguların, olumlu duyguları bastırmak ve neşeli aktivitelerden kaçınmak gibi faaliyetlerde bulunmasına yol açacağı ve mutluluk korkusuna sahip bireylerin yaşamlarında daha az olumlu duygu yaşadıkları sonucu elde edilmiştir (Joshanloo ve Weijers, 2014). Gilbert ve diğerlerinin (2012) şefkat ve mutluluk korkusu arasındaki ilişkiye dair araştırmasında ise, bunlara duyulan korkunun; aleksitimi, dikkat, empati, öz eleştiri, depresyon, kaygı ve stres ile bağlantılı olduğu ortaya konmuştur. Olumlu duygular korkularını ele almak adına gerçekleştirilecek müdahalenin önemli hedeflerinden biri öz-duyarılığı geliştirmektir. Olumsuz duygularla başa çıkmada kendine ve başkalarına merhamet sahibi olmak önemlidir (Gilbert ve diğerleri, 2014). Böylece bireyin kendine ve diğerlerine olan merhamet ve anlayışını içiren öz-duyarlılı̆ın mutluluk ve olumlu duygular korkusunu azaltacağı, ilgili alanyazında desteklenmektedir.

Araştırma sonucunda elde edilen bir diğer bulgu, öz duyarlılı̆ın duyguları ifade etme üzerinde kolaylaştırıcı bir etkisinin bulunmasıdır. Öz duyarlılık; bireyin kendi acılarına açık olma, şefkat duyguları yaşayarak, bireyin kendi yetersizliklerine ve başarısızlıklarına karşı anlayış ile gerçekçi bir tavır takınmasını, birey olmaktan kaynaklı yaşantıların ortak olarak paylaşıldığı anlayışı ile bireyin olaylara, duygu ve düşüncelerine açık bir şekilde yaklaşmasını içerir (Neff, 2003). Bireyin olumsuz deneyimlerine dahi anlayışla yaklaşmasını ve duygularını açık olarak ele almasını öngören öz duyarlılık, duyguları ifade etme üzerinde olumlu bir etkiye sahiptir. Araştırma bulguları bu sonucu desteklemektedir. Neff 'in (2009) bir diğer araştırması, öz-duyarlılığın psikolojik iyi oluş ile güçlü bir şekilde ilişkili olduğunu göstermektedir. Daha yüksek öz-duyarlılık seviyesinin; artan mutluluk, iyimserlik, merak ve bağlııı duygularının yanı sıra azalan kaygı, depresyon, ruminasyon ve başarısızlık korkusuyla bağlantılı olduğunu ortaya koymuştur. Ayrıca özşefkat, duygusal zekâ ve bilgelik ile güçlü bir şekilde ilişkilidir (Neff, 2009). 
Yapılan analizler sonucunda öz-duyarlılığın mutluluk korkusu ve duygularını ifade etme arasındaki ilişkide aracılık rolü test edilmiş, oluşturulan kuramsal model doğrulanmış ve öz-duyarlılığın manidar düzeyde aracılık etkisinin olduğu bulunmuştur. Joshanloo (2017), mutluluk kırılganlığı ve korkusunun mutluluğa etkisinde iyimserliğin aracılık rolünü incelemiş; mutluluk korkusunun mutlulukla negatif ilişkide olduğu, iyimserlik boyutu etkili olunca aradaki ilişkinin daha ılımlı bir sonuç gösterdiğini bulmuştur. Sonraki çalışmalar için ise mutluluğa ilişkin potansiyel moderatörleri tanımlamanın gerekliliğini vurgulamıştır. Joshanloo (2018)'deki çalışmasında ise mutluluk korkusu ve kırılganlığının, güvensiz bağlanma ve öznel iyi oluş arası ilişkide de aracılık etkisini incelemiştir. Güvensiz bağlanma, mutluluk korkusu ve mutluluk kırılganlığı ile pozitif yönlü bir ilişkiye sahiptir. Bu bulguyu destekleyen Gilbert ve diğerleri (2014), mutluluğun korkularının depresyon, anksiyete ve stresin en iyi yordayıcısı olduğunu ortaya koymuştur. Bulgulara göre aleksitimi (duyguları fark etme, tanıma ve ifade etme güçlüğü) depresyonu yönlendirememekte; mutluluk ve kendine şefkat korkusu depresyona aracılık etmektedir. Merhamet korkusu güvensiz bağlanma biçimi ile açıklanmış, güvensiz bağlanan bireylerin; yardım ve destek aramanın, etkisiz, ulaşılamaz, güvenilmez veya tehlikeli olabileceği düşüncesi ile diğerlerinden yardımseverlik ve merhametten korkacakları görüşü öne sürülmüştür (Gilbert, 2014). Sonuç olarak özduyarlılığı daha yüksek bireyler daha az aşırı tepki, daha az olumsuz duygular içerisinde olacaktır (Yarnell ve diğerleri, 2015). Olumsuzluğa yol açacağı gerekçesiyle kaçınılan ve korkulan mutluluk duygusunun ise öz-duyarlılık sayesinde daha çok deneyimleneceği ve böylece duyguları ifade etmenin kolaylaşacağı söylenebilir.

Mutluluk korkusuna aracılık edebilecek değişkenlere dair Türkiye'de yapılan bir çalışma bulunmamaktadır. Bunun yanı sıra araştırma verileri Marmara Üniversitesi'nin Atatürk Eğitim Fakültesi'nde öğrenim gören öğrencilerden elde edilmiştir ve genellenebilirlik açısından sınırlıdır. Yapılan çalışmada cinsiyet grupları açısından öz duyarlık puanları arasında manidar bir farklılık bulunmamıştır. Çalışma daha büyük örneklem gruplarında tekrarlanabilir. Araştırmadaki kadın oranının fazlalığı da göz önünde bulundurularak, duyguları ifade etme ve cinsiyet değişkeni üzerine de yeni çalışmalar yapılabilir. Sınırlılıklara rağmen yapılan araştırmanın pozitif psikoloji alanyazınına önemli bir katkı sağlayacağı, henüz yeni çalışılan mutluluk korkusu kavramının anlaşılması için gelecek araştırmalara öncülük edeceği düşünülmektedir.

\section{Kaynakça}

Adıgüzel, G. (2012). Üniversite öğrencilerinin saldırganlık düzeylerinin empatik eğilim, duyguları ifade etme ve öz anlayış açısından incelenmesi (Yüksek lisans tezi). Selçuk Üniversitesi, Eğitim Bilimleri Enstitüsü, Konya.

Akarsu, B. (1998). Mutluluk ahlakı. İstanbul: İnkılap.

Akın, Ü., Akın, A., \& Abacı, R. (2007). Öz-duyarlık Ölçeği: Geçerlik ve Güvenirlik Çalışması. Hacettepe Üniversitesi Eğitim Fakültesi Dergisi, 33, 1-10.

Demirci, İ., Ekşi, H., Kardaş, S. ve Dinçer, D. (2016). Mutluluk Korkusu Ölçeği'nin Türkçe formunun geçerlik ve güvenirliği. Kastamonu Eğitim Dergisi, 24(4), 2057-2072.

Diener, E., Seligman, E.P. (2002). Very Happy People. Psychologisal Science, 13(1), 81-84.

Gilbert, P., McEwan, K., Catarino, F., Baiao, R. ve Palmeira, L. (2014). Fears of happiness and compassion in relationship with depression, alexthymia, and attachment security in a depressed sample. British Journal of Clinical Psychology, 53, 228-244.

Gilbert, P., McEwan, K., Gibbons, L., Chotai, S., Duarte, J., Matos, M. (2012). Fears of compassion and happiness in relation alexthymia, mindfulness and self-criticism. Psycology and Psychotherapy: Theory, Research and Practice, 85, 374-390.

Goleman, D. (2001). Duygusal Zeka Neden IQ'dan Daha Önemlidir? (19.Basım). (Banu Seçkin Yüksel, Çev.). İstanbul: Varlık Yayınları

Greenberg, L. S. (2015). Duygular ve Duygusal Zeka. S. Balcı- Çelik (Ed.) Duygu Odaklı Terapi (ss. 3-38). Ankara: Nobel.

Joshanloo, M. (2013). The influence of fear of happiness beliefs on responses to the satisfaction with life scale. Personalitiy and Individual Differences, 54, 647-651. https://dx.doi.org/10.1016/j.paid.2012.11.011

Joshanloo, M. (2018). Fear and frafility of happiness as modiators of the relationship between insecure attachment and subjective well-being. Personalitiy and Individual Difference, 123, 115-118.

Joshanloo, M., Park, Y. O., Park, S. H. (2017). Optimism as the moderator of the relationship between of happiness beliefs and experienced happiness. Personalitiy and Individual Difference, 106, 61-63. 
Joshanloo, M., Weijers, D. (2014). Aversion to happiness across cultures: A review of where and why people are averse to happiness. J Happiness Stud, 15. 717-735.

Joshanloo, M., Weijers, D., Jiang, D-Y., Han, G., Bae, J., Pang, J.S., .. ve Natalia, A. (2015). Fragility of Happiness Beliefs Across 15 National Groups. Journal of Happiness Studies, 16 (5), 1185-1210. doi:10.1007/s10902-014-9553-0

Kuyumcu, B. (2011). Üniversite öğrencilerinin duygusal farkındalık, duyguları ifade etme, benlik kurgusu ve Öznel iyi oluş durumları Aarasındaki ilişkinin incelenmesi. Uluslar arası Sosyal Bilimler Eğitimi Dergisi 1(2), 104-113.

Kuzucu, Y. (2006). Duyguları Fark Etmeye ve ifade Etmeye Yönelik Bir Psikoeğitim Programının Üniversite Öğrencilerinin Duygusal Farkındalık Düzeylerine, Duyguları İade Etme Eğilimlerine, Psikolojik ve Öznel İyi Oluşlarına Etkisi. Doktora tezi. Ankara Üniversitesi Eğitim Bilimleri Fakültesi. Ankara.

Kuzucu, Y. (2011). Duyguları İfade Etme Ölçeği'nin uyarlanması: Geçerlik ve güvenirlik çalışmaları. Kastamonu Eğitim Dergisi 19(3), 779-792.

Neff, K. (2009). The Role of Self-Compassion in Development: A Healthier Way to Relate to Oneself. Human Development, 52, 211-214.

Neff, K. D. ve Vonk, R. (2009). Self-compassion versus global self-esteem: Two different ways of relating to oneself. Journal of personality 77(1), 23-50. doi: 10.1111/j.1467-6494.2008.00537.x

Neff, K.D. (2003). The Development and Validation of a Scale to Measure Self-Compassion. Self and Identity 2(3), 223250. DOI: $10.1080 / 15298860309027$

Özyeşil, Z. (2011). Üniversite öğrencilerinin öz-anlayış düzeylerinin bilinçli farkındalık kişilik özellikleri ve bazı değişkenler açısından incelenmesi (Doktora tezi). Selçuk Üniversitesi, Sosyal Bilimler Enstitüsü, Konya.

Preacher, K. J. ve Lronardelli, G. (2012). Calculation for the sobel test an interactive calculation tool for mediation tests. Web: http://people.ku.edu/ preacher/sobel/sobel.htm. (Erişim tarihi: 17.12.2012).

Salant, P. ve Dillman, D. A. (1994). How To Conduct Your Own Survey. Newyork: John Wiley \& Sons.

Sarı, T. (2016). Mutluluk korkusu ile öznel ve psikolojik iyi oluş arasındaki ilişkinin incelenmesi. Eğitim ve Öğretim Araştırmaları Dergisi, 5, 222-229.

Yarnell, L. M., Stafford, R. E., Neff, K. D., Reilly, E. D., Knox, M. C., \& Mullarkey, M. (2015). Meta-analysis of gender differences in self-compassion. Self and Identity, 14(5), 499-520. http://dx.doi.org/10.1080/15298868.2015.1029966 